Páipéar Taighde Teicniúil

Research Technical Paper

Bank Asset Quality ${ }_{G}$ Monetary Policy Pass-Through

David Byrne and Robert Kelly 


\title{
Bank Asset Quality \& Monetary Policy Pass-Through
}

\author{
David Byrne and Robert Kelly* \\ Monetary Policy Division, Central Bank of Ireland
}

December 2017

\begin{abstract}
The funding mix of European firms is heavily weighted towards bank credit, underscoring the importance of efficient pass-through of monetary policy actions to lending rates faced by firms. Euro area pass-through has shifted from being relatively homogenous to fragmented and incomplete since the financial crisis. Distressed loan books are a crisis hangover with direct implications for profitability, hampering banks ability to supply credit and lower loan pricing in response to reductions in the policy rate. This paper presents a parsimonious model to decompose the cost of lending and highlight the role of asset quality in diminishing pass-through. Using bank level data over the period 2008-2014, we empirically test the implications of the model, with results showing that asset quality, measured through a one percentage point increase in the impairment ratio have a significant negative impact, lowering immediate pass-through by 3 per cent. For impairment rates greater than 17 per cent, we find that pass-though is not significantly different from zero. We derive a measure of the hidden bad loan problem, the NPL gap, which we define as the excess of NPLs over impaired loans. We show it played a significant role in the fragmentation of euro area pass-through post-crisis.
\end{abstract}

JEL Classification: D43, E51, E52, E58, G21

Keywords: Monetary Policy Pass-through, Impaired Loans, Non-Performing Loans, Interest Rates

\footnotetext{
${ }^{*}$ E-mail: david.byrne@centralbank.ie \& robert.kelly@centralbank.ie. The views presented in this paper are those of the authors alone and do not represent the official views of the Central Bank of Ireland or the European System of Central Banks. Any remaining errors are our own.
} 


\section{Non-Technical Summary}

Small and medium firms account for 70 per cent of the employment in the euro area. This makes them a priority for the transmission of ECB non-standard monetary policies to growth and inflation. The direct impact of these polices could be limited due to less developed fund sources available to small firms. To assess the impact of monetary policy decisions on this group, it is paramount to examine the credit channel. This is the channel the price and supply of credit reflect changes in the policy rate and lower bank funding costs due to non-standard measures. Euro area pass-through has shifted from being relatively homogenous to fragmented and incomplete since the financial crisis. While sovereign risk plays a role, the direct implications for bank profitability from distressed lending hamper banks ability to supply credit and lower loan pricing in response to reductions in the policy rate.

This paper derives a parsimonious model decomposing the drivers of loan pricing into the contribution of the policy rate, default risk, loss given default, sovereign bond yield, market concentration and sensitivity of capital to new lending. This allows us to characterise the channels through which asset quality diminishes pass-through of policy rate changes. Using micro data at the bank level covering 2008-2014, we test the implications of the model for adjustment of lending rates. Results show that asset quality has a significant negative impact on pass-through, slowing 3 per cent for a percentage point increase in impairments. In addition, pass-though is not significantly greater than zero for impairment rates above 17 per cent.

Distressed loan books erode limited bank capital an imped the ability of impairments to keep pace with new bad loans. Therefore, focusing on impairments could underestimate the size of the bad loan problem. To assess the potential we calculate an NPL gap for each bank, as the difference between NPL and impairment ratios. This gap is significant, growing with level of non-performing loans. We find that excess non-performing loans further diminish pass-through to lending rates, controlling for the direct effect of impairments. Further, there is a clear concentration of the NPL gap with the stressed countries and thus these play a key role in explaining the fragmentation of pass-through rates since 2008. This underlines the importance of realisation and resolution of bad loans to lower loan pricing and improve the functioning of supply to Europe's bank credit dependent firms. 


\section{Introduction}

The post-financial crisis period of sluggish growth and low inflation resulted in substantial monetary policy easing by major central banks: policy rates were cut to zero and large scale asset purchase programmes launched. From a European perspective, evaluating the stimulatory impact of these policies on credit supply is paramount. European firms face a less-developed market for alternatives to bank finance compared with their U.S. counterparts ${ }^{1}$. The efficiency of the credit channel depends on the efficient pass-though of changes in policy rates to loan pricing. This pass-through has however become fragmented across European countries post-crisis (Ciccarelli et al., 2013). The financial stability impact from the financial crisis on the euro area banking sector has been similarly heterogeneous. Some banks have not faced substantial changes in risk from their pre-crisis levels. Some have realised risks from over-heated property sectors. Other banks still have borne risks from stressed sovereigns. Within countries, sovereign stress affects banks in a common manner and does not pose a direct threat to bank profitability in the absence of a default event. However, non-performing loan (NPL) rates display vary greatly between banks based on lending practices and sector concentration. Importantly, NPLs directly impact bank profitability and solvency. Their key role for recovery has been recognised by the European Central Bank (ECB), stating that "the deliberate and determined reduction in nonperforming loans is essential for the viability of the European banking sector. It therefore constitutes a necessary condition for the recovery of the euro area economy" 2 .

High NPL ratios have implications for both the price and quantity of credit. They directly impact profitability through reducing net interest margins and require banks to hold additional capital which otherwise could boost lending. In addition, new loan pricing must reflect the higher risk weighting caused by distressed loan books and potentially be increased to offset loans which are not bearing interest. Our contribution to the stock of literature is two-fold. Firstly, extending Ruthenberg and Landskroner (2008), we derive a parsimonious model to decompose the cost of lending and characterise the channels through which asset quality impacts pass-through. Secondly, using bank-level data over the period 2008-2014, we empirically test the implications of the model for both short- and long-run adjustment of lending rates to policy rate shifts controlling for competition, sovereign risk, liquidity and impairments concurrently. Results show asset quality have a significant negative impact. Further for impairment rates greater than 17 per cent, pass-though is not significantly greater from zero.

The pass-through of monetary policy actions across the euro area is a well-investigated topic, initially focusing on the joining of monetary union (Marotta, 2009) and resulting gains in the speed

\footnotetext{
${ }^{1}$ The ECB conducts a semi-annual Survey on the Access to Finance for Enterprises (SAFE) showing more than $50 \%$ of firms use bank finance compared to $25 \%$ in the U.S.

${ }^{2}$ From Donnery (2017), a speech by the chair of the ECB working group on non-performing loans. The working group has published guidelines for supervised banks to reduce current NPL levels in a timely manner. For further details, see https://www.bankingsupervision.europa.eu.
} 
and homogeneity of pass-through (Sander and Kleimeier, 2004). More recently, research has focused on the post-financial crisis era, showing increased fragmentation across countries (Ciccarelli et al., 2013; Aristei and Gallo, 2014) and less completeness of pass-through (Hristov et al., 2014). This divergence has been explained by higher funding costs (Illes et al., 2015), funding uncertainty (Ritz and Walther, 2015) and the changing marginal cost of raising deposits (Avouyi-Dovi et al., 2017). The use of micro data on banks balance sheets has grown to help understand the factors underlying these changes. They point to the importance of bank-specific characteristics, in addition to macro variables in explaining developments in pass-through (Gambacorta, 2008; Holton and Rodriguez d'Acri, 2015). Similar to the US, size (Kashyap and Stein, 1995), liquidity (Kashyap and Stein, 2000) and capital ratios (Kishan and Opiela, 2000) are key to lending rates adjusting to policy changes.

The post-crisis overhang of bad loans has brought the macroeconomic impact into sharp focus. In a recent speech, Constâncio (2017) provides estimates showing NPL resolution yields increases in credit supply of 2.5 to 6 per cent in countries with higher ratios. Balgova et al. (2016) estimates the damage of prolonged periods of a high NPL ratio, finding 2 per cent of growth is foregone annually. On the bank side, along with reducing credit supply, NPLs distort credit allocation, cause market uncertainty and act as a drag on economic growth (Kwan and Eisenbeis, 1995; Cucinelli, 2015; Jorda et al., 2013; Peek and Rosengren, 2000, 2005). Exploiting credit registry information, Jiménez et al. (2012) separate demand and supply side effects, showing the significant negative role of existing or previous bad debts on the firm side in the granting of new credit.

Our paper is linked to the growing broad body of research considering loan pricing in the period of non-standard measures. Acharya et al. (2015) assesses the impact of the switch to full rate allotment action, with no significant impact on the corporate loan spreads of high risk banks. As the crisis intensified, policy rates fell to the zero lower bound and asset purchase programmes were launched. Recent developments include using term structure modeling to develop a "shadow rate". These developments take significantly negative values to account for these non-standard policies (Wu and Xia, 2016; Lemke and Vladu, 2016), and the use of event study methodology on financial variables (Altavilla et al., 2015, 2016), both showing a significant compression in lending margins and associated macroeconomic gains. This paper does not consider the pass-through of non-standard measures as this requires a different empirical approach to convergence when comparing lending rates close to the zero lower bound with those up to 4 percentage points higher at the beginning of the ECB's Expanded Asset Purchase Programme.

When the share of non-performing loans is growing, a bank's impairments may not keep pace with its NPLs if the bank has a limited capital reserve. Thus, to investigate the possibility of impairments underestimating the full extent of the bad loan problem, we calculate an "NPL gap" for each bank, defined as the difference between the NPL and impairment ratios. This gap grows significantly in the 
NPL ratio, with an average of less than half the loans being impaired for NPL ratios above 10 per cent. Estimates show this gap increases lending rates and reduces immediate pass-though by levels comparable to impairments. Furthermore, the NPL gap is clearly concentrated within the stressed countries and it is key in explaining the divergence in pass-through rates since 2008. This underlines the importance of asset quality reviews, with bad loans efficiently realised and resolved to lower loan cost and improve the functioning of euro area credit supply from banks.

The rest of this paper is structured as follows: Section 2 outlines a theoretical framework in which the asset quality affects the pass-through of monetary policy. Section 3 presents the data. Section 4 outlines the empirical strategy and provides empirical results. Section 5 compares the impairment and NPL ratios and examines the consequences for pass-through from the existence of a non-perfoming loan overhang. Finally, section 6 concludes.

\section{Theory}

Following Ruthenberg and Landskroner (2008), we develop a model of a risk-neutral commercial bank which operates in an imperfectly-competitive lending market for non-financial corporation (NFC) credit. The basis for this model is an oligopolistic extension to the Monti-Klein model of a monopolistic bank, as outlined in Freixas and Rochet (2008) The bank raises deposits from the public and may also raise funds on the interbank market. We extend the previous literature by allowing the state of the bank's balance sheet to affect the pricing of its loans. Furthermore, we allow the recoverability of debt, in the event of default, to affect loan pricing.

Let $L\left(R_{L}, \alpha\right)$ represent the aggregate demand for credit from the banking system, which is decreasing in the lending rate $R_{L}$ and depends on a shift parameter $\alpha$, which can represent macro conditions and other factors which may affect aggregage credit demand. Let $P D \in(0,1)$ be the "throughthe-cycle" probability of default for lending, which we assume to be symmetric between banks. Let $L G D \in(0,1)$ be the loss given default for a loan, i.e. the share of the loan which is not recoverable given a default event occurs. Thus we can say that the return on lending for bank $i$ is given by:

$$
\begin{cases}\left(1+R_{L}\right) L_{i}\left(R_{L}, \alpha\right) & \text { with probability }(1-\mathrm{PD}) \\ (1-L G D) L_{i}\left(R_{L}, \alpha\right) & \text { with probability PD. }\end{cases}
$$

Similarly, we define $D\left(R_{D}, \beta\right)$ as the supply function for deposits from the public, which is increasing in the interest rate paid on deposits, $R_{D}$ and depends on a shift parameter $\beta$ which captures the impact of macroeconomic conditions on the supply of deposits. We also define $r \in(0,1)$ as the reserve requirement on deposits. Let $Z_{i}=\left[L_{i}(\cdot)-(1-r) D_{i}(\cdot)\right]$ be the shortfall in funding for bank $i$, which 
we assume to be positive without loss of generality. The bank may borrow in the interbank market at interest rate $R_{w}$ to fund this shortfall. We assume that the interbank rate is a function of the interest rate $R_{m}$ set by the monetary policy authority, i.e. $R_{w}=f\left(R_{m}\right)$ where $f(\cdot)$ is a continuous, differentiable function with $f^{\prime}(\cdot)>0$. The bank may also issue bonds, the yield of which $Y_{b}$ is assumed to be a function of the yield on the sovereign $Y_{s}$, i.e. $Y_{b}=h\left(Y_{s}\right)$ where $h(\cdot)$ is a continuous, differentiable function with $h^{\prime}(\cdot)>0$. Let the shares of inter-bank lending and issuance of bonds with respect to the funding shortfall be given by $\gamma$ and $(1-\gamma)$ respectively.

The bank is required by the regulator to be sufficiently capitalised against unexpected losses. We thus define $K_{i}\left(L_{i}, L^{S}\right)$ as the capital of the bank, which is increasing both in new lending $L_{i}$, and the stock of existing lending $L^{S}$. The interpretation of the stock of lending can include lending in other markets, i.e., to households as well as to NFCs. The return on equity is given by $R_{e}$ which is a function of the monetary policy rate, i.e. $R_{e}=g\left(R_{m}\right)$ wherewhere $g(\cdot)$ is a continuous, differentiable function with $g^{\prime}(\cdot)>0$. The bank may raise equity in equity markets at this rate, to satisfy its capital requirements.

We allow that a share of the bank's outstanding lending does not perform. We assume that the bank takes impairment charges against its non-performing loans, thus realising a cost from having a stock of loans of this type. We denote the ratio of impaired loans to total loans as $I M P$ and, intuitively, the effect of impairments on bank capital is negative:

$$
\frac{\partial K}{\partial I M P}<0
$$

The short-run expected profits of the commercial bank are given by:

$$
\begin{aligned}
E\left(\Pi_{i}\right)= & (1-P D)\left(1+R_{L}\right) L_{i}\left(R_{L}, \alpha\right)+P D(1-L G D) L_{i}\left(R_{L}, \alpha\right)-\left(1+R_{D}\right) D_{i}\left(R_{D}, \beta\right) \\
& -\left[\gamma\left(1+R_{w}\right)+(1-\gamma)\left(1+Y_{b}\right)\right]\left[L_{i}(\cdot)-(1-r) D_{i}(\cdot)\right]-R_{e} \cdot K_{i}\left(L_{i}, L^{S}\right)-F_{i}
\end{aligned}
$$

where $F_{i}$ is a fixed cost of operation for the bank, incorporating its branch network and other factors. Taking the derivative of (3) with respect to $L=\Sigma_{i} L_{i}(\cdot)$, yields the following first order condition:

$$
\begin{gathered}
\frac{\partial \Pi_{i}}{\partial L}=(1-P D)\left(1+R_{L}\right) \frac{\partial L_{i}}{\partial L}+(1-P D) L_{i}(\cdot) \frac{\partial\left(1+R_{L}\right)}{\partial L}+P D(1-L G D) \frac{\partial L_{i}}{\partial L} \\
-\gamma\left(1+R_{w}\right) \frac{\partial L_{i}}{\partial L}-(1-\gamma)\left(1+Y_{b}\right) \frac{\partial L_{i}}{\partial L}-R_{e} \cdot \frac{\partial K_{i}}{\partial L}=0 .
\end{gathered}
$$

Note that $L_{i}(\cdot) \frac{\partial\left(1+R_{L}\right)}{\partial L}=-\frac{s_{i}}{\epsilon} R_{L}$ where $s_{i}$ is the share of lending of bank $i$ in aggregate lending, $L_{i} / L$ and $\epsilon$ is the elasticity of loan demand to the interest rate on lending. Multiplying by $s_{i}$, summing 
over banks, and using the Cournot assumption that $\Sigma_{i} s_{i} \frac{\partial L_{i}}{\partial L}=1$, yields the following equivalance of Marginal Revenue and Marginal Cost:

$$
(1-P D)\left(1+R_{L}\right)\left(1-\frac{H}{\epsilon}\right)+P D(1-L G D)=\gamma\left(1+R_{w}\right)+(1-\gamma)\left(1+Y_{b}\right)+R_{e} \cdot \frac{\partial K_{i}}{\partial L_{i}}
$$

where $H=\Sigma_{i} s_{i}^{2}, H \in(0,1)$ is the Herfindahl-Hirschmann index of concentration in lending. Rearranging equation (5), and substituting for $R_{w}, Y_{b}$ and $R_{e}$ yields the loan pricing equation:

$$
\left(1+R_{L}\right)=\frac{1+\gamma f\left(R_{m}\right)+(1-\gamma) h\left(Y_{s}\right)+g\left(R_{m}\right) \cdot \frac{\partial K_{i}}{\partial L_{i}}-P D(1-L G D)}{(1-P D)\left(1-\frac{H}{\epsilon}\right)} .
$$

Proposition 1: The interest rate on lending, $R_{L}$, is increasing in:

(i) The probability of default, PD

(ii) Market concentration, $\mathrm{H}$

(iii) The loss given default, LGD

(iv) The sovereign bond yield, $Y_{s}$

(v) The sensitivity of capital to new lending, $\frac{\partial K_{i}}{\partial L_{i}}$.

Conversely, the interest rate on lending, $R_{L}$, is decreasing in:

(vi) The elasticity of credit demand to the interest rate, $\epsilon$.

Proof: See Appendix.

The pass-through of the monetary policy rate to the lending rate is given by the partial derivative of $R_{L}$ with respect to $R_{m}$ :

$$
\frac{\partial R_{L}}{\partial R_{m}}=\frac{\gamma f^{\prime}\left(R_{m}\right)+g^{\prime}\left(R_{m}\right) \cdot \frac{\partial K_{i}}{\partial L_{i}}}{(1-P D)\left(1-\frac{H}{\epsilon}\right)}>0 .
$$

Intuitively, the lending rate is an increasing function of the monetary policy rate. To determine the impact of impairments on the transmission mechanism, one must take the cross partial derivative of (7) with respect to the impairment ratio of the bank.

Proposition 2: The pass-through of changes in the monetary policy rate to changes in the lending rate is lower the higher the impairment ratio of the bank.

Proof: See Appendix. 


\section{Data}

To empirically evaluate the propositions in Section 2, we link data from a number of sources. We use two ECB datasets providing information on the balance sheets and loan pricing of euro area monetary financial institutions (MFIs): the Individual Balance Sheet Items (IBSI) dataset and Individual MFI Interest Rate statistics (IMIR) dataset. The former dataset provides detailed information on the assets and liabilities of euro area banks, including for instance granular information on their loans, liquid assets and deposits. The latter dataset encompasses granular data on the volume of, and interest rate on, each MFI's new lending to euro area non-financial corporations and households.

In this paper, we solely look at the lending rates to euro area non-financial corporations. Specifically, we focus on the pricing of lending rates on loans to NFCs on loans of up to $€ 1$ million in size and for up to one year of fixation; this includes loans which have adjustable rates at origination and loans which are fixed for up to to one year. We choose this category of lending for a number of reasons. First, this is the most common category of lending, and thus has the greatest data coverage across banks and through time. Second, this category of lending is the one in which we would expect to find the greatest degree of sensitivity of loan pricing to monetary policy, given the short-term nature of the lending. Third, we exclude loans with longer periods of fixation to avoid potential problems with the embedding of term premia and interest rate expectations in the prices of these products. Last, our datasets provide two size categories for loans: greater or less than $€ 1$ million. We focus on the category of loans less than $€ 1$ million, given that we are more likely to be observing lending over which the borrower is a price taker and to have little bargaining power over the price. Thus, we are more likely to cleanly identify bank-driven changes in loan pricing ${ }^{3}$.

To these datasets, we link additional information on the banks in our sample from other sources. Table 7 provides a full description of the data and sources which are used in this paper. The IBSI and IMIR datasets do not contain information on the impairment of the balance sheets of the banks, so we rely on information from the SNL Financial data provider. We are able to extract data on the asset quality of Europe's banks from this source, specifically focusing on the impairment ratio for its representation of the realisation of costly impacts from a non-performing positiion, as discussed in Section 2. The impairment ratio is given by the ratio of impaired loans, i.e., loans against which an impairment charge has been taken, to total loans. We also extract the ratio of non-performing loans from this source, where non-performing loans are defined as loans from which interest is no longer accruing. From the NPL ratio and impairment ratio, we are able to define an "NPL gap" measure, as

\footnotetext{
${ }^{3}$ In the literature, loans of up to $€ 1$ million in size are commonly chosen as a proxy for the SME credit market, given that the datasets do not allow the counterparty classification to be explicitly indentified (Holton and McCann, 2016). Individual loans which exceed $€ 1$ million in size are more likely to be taken out by large firms, which are more likely to have some degree of bargaining power over the price of the loan.
} 
Figure 1: Cumulative changes in lending rates

(a) Against changes in Eonia

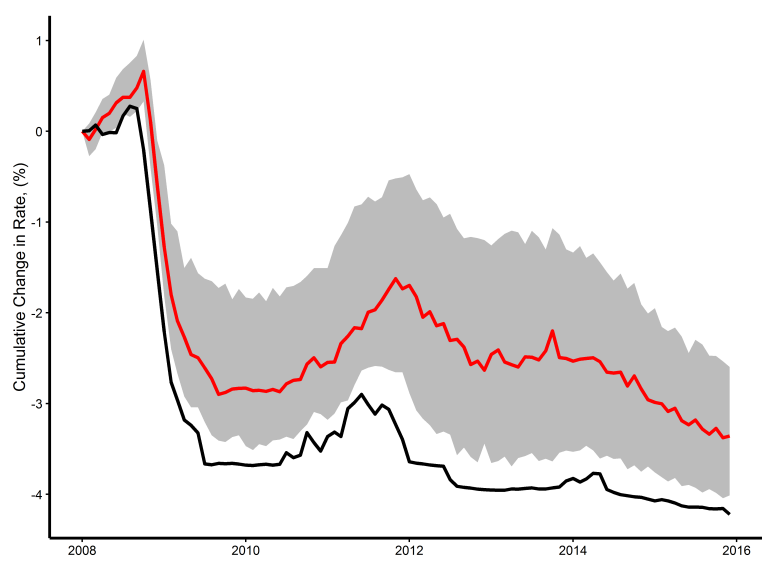

(b) By impairment ratio and sovereign yields

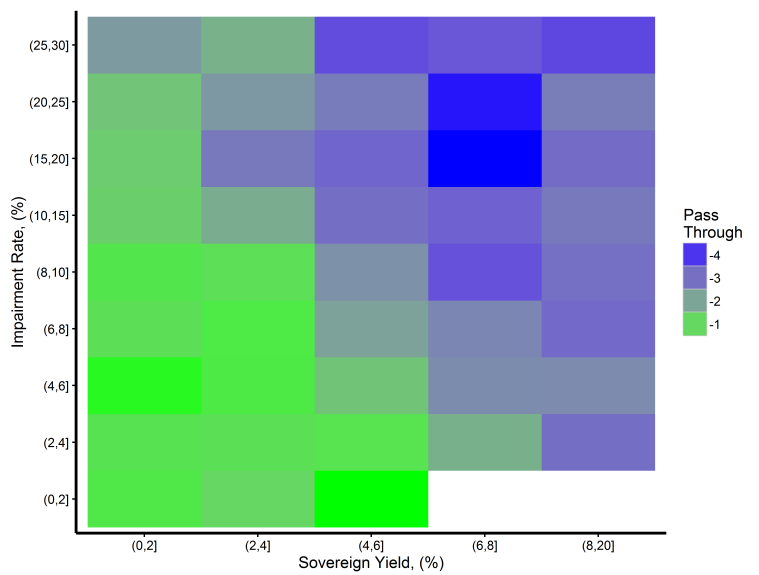

Notes: Figure 1a shows the cumulative change in Eonia (black line) since Jan. 2008, against the median cumulative change in bank lending rate, with shaded area showing the inter-quartile range. Figure $1 \mathrm{~b}$ shows the heatmap of categories of impairment rate and sovereign yield between Jan. 2008 and Dec. 2015. The colour scale captures cumulative passthrough, measured as the median lending rate less Eonia for each category.

the percentage point excess of the NPL ratio over the impairment ratio. We examine the impact of having an NPL overhang on pass-through in Section 5.

We take both the impairment and NPL ratios on a consolidated basis, i.e., accounting for the possible non-performance of a bank's lending book in other jurisdictions than its home market, if it has any lending of this type. Similarly, we account for the existence of banking groups in the euro area: we assign members of a banking group the consolidated impairment and NPL ratios of the banking group. This accounts for the possibility that the pricing of the loans issued by one member of a banking group can be driven by group-level asset quality, and affected by within-banking group subsidisation effects, rather than the non-performance of that member's previous loans on a residency basis. The impairment and NPL ratios are reported at half-yearly frequency, and we interpolate to monthly frequency using the method of Stineman (1980) .

Figure 1 depicts two ways in which we can visualise pass-through in our sample: how lending rates have evolved through time compared with the money market rate and how the degree of pass-through differs based on degrees of balance sheet impairment and sovereign stress. The left-hand panel shows the cumulative changes in the median lending rate in our sample in red, the cumulative change in Eonia in black, and the interquartile range shaded in grey. The median lending rate tracks Eonia quite closely between 2009 and 2011, including the monetary easing in 2009 and tightening in 2011. Thereafter, particularly between 2012 and 2014, there is a notable increase in dispersion of lending

\footnotetext{
${ }^{4}$ The results are also not sensitive to using a linear interpolation process.
} 
Figure 2: Scatter plot of cumulative pass-through to impairment level

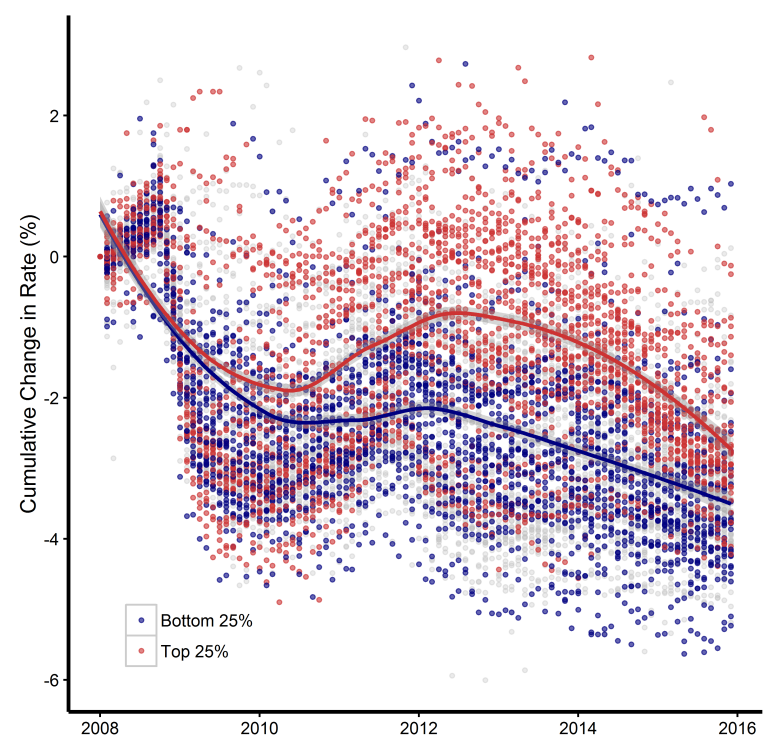

Notes: Figure 2 shows the cumulative change in individual banks' lending rate since Jan. 2008. The top and bottom $25 \%$ of the impiarment ratio is coloured red and blue respectively, with fitted lines and confidence intervals for each group.

rates. Latterly there has been some convergence of the lending rate toward the money market rate, and a decrease in dispersion.

The right-hand panel of Figure 1 shows a heatmap of the cumulative change in lending rate over the sample, i.e., a measure of overall pass-through. The vertical axis shows categories of the impairment ratio, while the horizontal axis shows categories of the yield of the sovereign. The most complete pass-through is shaded in green, while the least pass-through is shown in dark blue. Pass-through deteriorates the more stressed the sovereign and the higher the level of balance sheet impairment. However, there is also clear variation on the off-diagonal, consistent with the impairment ratio lowering pass-through for a given level of sovereign yield, and vice versa. This motivates our view that there is bank-level heterogeneity in pass-through in Europe, driven by non-performing loans, which is not adequately explained through country-level measures.

Figure 2 provides a scatter plot of the cumulative change in the NFC lending rate since 2008 against the impairment ratio, with fitted lines by quartile. The top quartile of the impairment ratio is coloured in red, the bottom quartile is coloured in blue, and the remaining quartiles are shaded in light grey. Pass-through appears to be more complete among banks in the bottom quartile of the impairment ratio, with lending rates decreasing by less among banks with higher levels of impairments. There is no significant difference in pass-through between groups in the initial stages of 2008-2010, but thereafter a divergence appears as balance sheets become increasingly impaired among some European 
banks. Among the highly-impaired banks, lending rates also increased by more during the period of tightening of the monetary policy stance in 2011. The divergence between the groups is greatest in 2013, at 1.5 percentage points. In 2015 and 2016, there has been some degree of convergence in lending rates between the banks in the top and bottom quartiles, with the banks in the top quartile lowering their lending rates. While the period we study is also characterised by sovereign stress in some countries, Figure 1b suggests that balance sheet impairment is a stand-alone factor which affects pass-through in its own right. In Section 4 we will employ statistical techniques to separate the impacts of these.

Table 5 includes summary statistics of each of the explanatory variables which we use in our estimations. We measure the concentration of European banking markets using Herfindahl indices available from the ECB. These capture the competitive structure of a country's lending market as a whole, not solely from banks in our sample. This also addresses the importance of other, non-bank, credit institutions which are particularly prevalent in certain European countries. The measures of concentration for each country are shown in Figure 6. We also use the asset shares of the five largest credit institutions in each country to represent market structure. We address bank size using total assets, which we include on a consolidated basis, following our treatment of balance sheet impairment. We measure bank liquidity using the share of liquid assets to total assets. This includes holdings of loans to, and securities from, other MFIs, and so can capture within-group positions. We use the share of non-financial private sector deposits in total liabilities to capture the funding structure of banks. We include CDS spreads, for the banks for which these are available, to capture bank credit risk.

Table 6 shows how lending rates differ by values of the explanatory variables in our model. We include the mean and standard deviation of the lending rate for the top and bottom quartiles of each variable. The mean lending rate for the whole sample is 4.1 per cent. For banks within the lowest quartile of the impairment ratio, this is 3.6 per cent, with lending rates on average one percentage point higher for banks in the top quartile of the impairment ratio. Given that balance sheet impairment increases through our sample, we also split banks by quartiles of the impairment ratio at three separate time points to show how there is variation in lending rates by impairment within time and not solely between time. In June 2010, there is a one percentage point difference between average lending rates in the top and bottom quartiles, while in June 2014 there is a 2.3 percentage point difference. Similarly, we find higher lending rates within the top quartiles of the NPL ratio and the NPL gap. We find that bigger banks, more liquid banks and banks with greater deposit-to-liability shares have lower lending rates, while banks in the top quartiles of market concentration and by CDS have higher lending rates. 


\section{Empirical Model and Results}

\subsection{Empirical Model}

One of the channels through which monetary policy can affect the real economy is the bank lending channel. Central banks may adjust their short term policy rate such that it affects the level of interest rates in the money market, and thereby have an impact of the cost of bank funding. This adjustment in the funding cost of the bank affects the supply of credit, with resulting impacts on the volume and price of bank lending. Given that our interest lies with credit supply, we follow Gambacorta (2008) throughout this paper in focusing on bank-specific variables which economic theory suggests affect the supply of loans but not loan demand. We also focus exclusively on identifying how the pricing of bank loans responds to changes in monetary policy as banks have direct control over loan pricing. To examine lending volumes would require separating supply and demand effects, with identification likely to be hampered by shifts in demand for credit (Jiménez et al., 2012).

Following Gambacorta (2008) and Holton and Rodriguez d'Acri (2015), we use a single equation error correction model to estimate the pass-through of changes in monetary policy to banks' lending rates. This approach allows us to capture both short- and long-term dynamics in interest rate setting. Equation (8) provides the exact formulation which we use: an Autoregressive-Distributed Lag specification, a detailed discussion of which is provided in Banerjee et al. (1990). We relate the monthly change in lending rate to non-financial corporations for bank $i$ at time $t, \Delta i r_{i, t}$, to the change in money market rate $\Delta m r_{t}$ and the lagged change in the bank's own lending rate $\Delta i r_{i, t-1}$. We also include an error term capturing the difference in lagged levels of the lending rate and the money market rate $\left(i r_{t-1}-m r_{t-1}\right)$. The error term tests the assumption of an equilibrium relationship between lending rate and money market rate; it must be significantly negative to support such an assumption. However, following Banerjee et al. (1990), we do not impose the assumption that a one-to-one long run relationship necessarily must hold between the lending rate and money market rate. As such, the $i r_{t-1}$ and $m r_{t-1}$ terms enter equation (8) separately.

$$
\begin{aligned}
\Delta i r_{i, t} & =\mu_{i}+\Delta i r_{i, t-1}+\left(\beta_{0}+\beta \mathbf{Z}_{i, t-1}\right) \Delta m r_{t}+\left(\delta_{0}+\delta \mathbf{Z}_{i, t-1}\right) i r_{i, t-1} \\
& +\left(\theta_{0}+\theta \mathbf{Z}_{i, t-1}\right) m r_{t-1}+\lambda \mathbf{Z}_{i, t-1}+\gamma \mathbf{X}_{k, t}+\epsilon_{i, t} .
\end{aligned}
$$

Our model includes bank fixed effects, denoted by $\mu_{i}$, to capture unobservable heterogeneity between banks in the setting of interest rates. We address the possibility of heterogeneity between banks in pass-through to their lending rates by introducing a vector of bank-specific variables, $\mathbf{Z}$, to the model. These variables are described fully in Table 7 , and are lagged to mitigate endogeneity concerns. The 
bank-specific variables are interacted with the change in money market rate, $\Delta m r_{t}$, to investigate how they affect immediate pass-through. Furthermore, they are interacted with the components of the error term to investigate if there is heterogeneity in the long run elasticity of lending rate to money market rate. Finally, we also allow the bank-specific variables and a vector of macroeconomic variables, $\mathbf{X}$, to have direct effects on the interest rate setting.

Immediate pass-through to lending rates is given by aggregating the terms in $\beta$, i.e., the sum of the main effect of the change in the money market rate, $\Delta m r_{t}$, and of the interaction of this with the levels of the bank-specific variables:

$$
\beta_{0}+\beta \overline{\mathbf{Z}}_{t-1}
$$

where $\overline{\mathbf{Z}}_{t-1}$ denotes the mean of the bank-specific variables. The measure of immediate pass-through given by (9) describes how much of a unit change in the money market rate is passed-through to the lending rate, controlling for the impact of bank characteristics. We examine the long-run elasticity of the lending rate to the money market rate in similar fashion. The terms in $\delta$ and $\theta$ in equation (8) capture the impact of the levels of the lending and money market rates, aggregated as in the case of the measure of immediate pass-through. We can express the long run elasticity by the ratio of the $\delta$ and $\theta$ expressions:

$$
-\left(\frac{\theta_{0}+\theta \overline{\mathbf{Z}}_{t-1}}{\delta_{0}+\delta \overline{\mathbf{Z}}_{t-1}}\right)
$$

With full long run pass-through, this ratio would be equal to unity. The $\delta$ expression may itself also be interpeted as giving the adjustment dynamics of the system: it expresses the share of a disequilibrium position between lending rate and money market rate which is closed in the next time period.

Our model features a lagged dependent variable and individual fixed effects. Given our panel is at monthly frequency ( $\mathrm{T}=78$ ), however, we have sufficiently long time series to mitigate concerns relating to bias arising from the dynamic panel data structure (Nickell bias). In our main specifications, we thus employ the fixed-effects estimator to estimate equation (8), with robustness checks featuring pooled Ordinary Least Squares. The money market rate we choose is Eonia. Time-invariant funding premia over Eonia would not be a concern for our model, as we are interested in how changes in the money market rate are passed through to the lending rate. However, there may be concerns relating to timevarying premia, i.e., that certain banks experience periods in which they cannot fund themselves at a rate close to Eonia. To address this, we include robustness checks in which we interact Eonia with a bank-specific Credit Default Swap spread, which should capture the periods in which the bank's own funding cost is elevated relative to the market rate.

Our parameter of interest is the impairment ratio, which captures the costly impact on the bank from the impairment of its balance sheet. In Section 2, we derived an analytical prediction for the sign of the impact of balance sheet impairment on pass-through. We empirically validate this prediction 
and measure the magnitude of the impact on pass-through. Given that our time period does not exclusively feature easing of the monetary policy stance, we are also able to test for symmetry of the effect of impairments on pass-through. Peltzman (2000) documents the phenomenon of asymmetric cost pass-through in approximately two-thirds of 242 markets studied, whereby prices rise faster than they fall, while symmetry of cost pass-through is observed in approximately a third of cases.

We focus on the impairment ratio, rather than the non-performing loan ratio, because the impairment ratio offers the cleaner measure of how an impaired balance sheet can affect interest rate pricing. While the impairment ratio clearly depends upon the non-performing loan ratio, the impairment ratio represents the realisation of costs arising from a stock of non-performing loans. As we outline in our theoretical model, it is the costly nature of the problem which leads to a change in the pass-through behaviour to lending rates. The NPL ratio itself is not as clean a measure of costly balance sheet impairment because there may be variation in the degree to which banks realise impairment charges from their non-performing loans. In the Appendix, we include robustness checks in which we use the NPL ratio itself.

To capture the impact of competition on interest rate pricing, our baseline model includes a measure of country-specific concentration in the banking market. As shown in Figure 6, there are intuitively substantial differences in the structures of European banking market, as shown by level differences in the Herfindahl indices between countries. However, given that we are using the within transformation, what matters is that we account for how concentration changes in the sample. As the left-hand panel of Figure 6 indicates, there is also a significant degree of within country variation in concentration throughout the time period we study. The range is shaded in grey, with the values in 2008 and 2014 highlighted in red and blue, respectively. The right-hand panel of the figure also plots average lending rates for banks above and below the median value of the concentration measure, with pass-through worse in markets with a high degree of concentration.

Following the literature, we control for bank size and liquidity in our loan-pricing equation (Kashyap and Stein, 2000; Gambacorta, 2008; Gambacorta and Mistrulli, 2014). Economic theory suggests that both larger and more liquid banks should have better pass-through. We depart from the previous literature in that we do not include bank capital in our main specification. We do this as our interest lies in the adjustment to the pricing of short-term credit by banks which face costly impairment charges as a result of having a stock of non-performing loans. As outlined in Section 2, these charges come through the bank capital channel. We thus omit bank capital so as to cleanly identify the impairment effect. Another reason to consider omitting bank capital relates to the endogeneity of capital in European banking in the period we study. A number of banks in Europe received recapitalisations in the post-financial crisis era (Brei et al., 2013). As a result, there is good reason to expect there to be reverse causality between interest rate pass-through and bank capital. 
To control for macroeconomic conditions, we include the country-specific unemployment rate, inflation rate and 10 year government bond yield in our main specification. The unemployment and inflation rates capture economic conditions, and thus serve as a proxy for credit demand (Kashyap et al., 1993). We thus expect a-priori that there should be a positive relationship with interest rates for both. We include the sovereign bond yield to address the sovereign-banking nexus which was a feature of European banking during our sample. As outlined in Section 2, we expect that a tightening in financing conditions, as represented by an increase in sovereign bond yields, should be reflected in an increase in the funding cost of banks. We thus expect that lending rates on bank credit should rise as a result. As shown in the Appendix, our results are not sensitive to whether the macroeconomic variables are expressed in levels, changes, or both. We also include robustness checks in which we include country-year fixed effects, which should address concerns relating to unobserved country- and time-specific factors.

We include a number of additional robustness checks for our pass-through model. To examine the role that the funding structure of a bank has on its loan pricing, we control for the share of deposits from the non-financial private sector in all liabilities. This addresses how the stability of a bank's funding profile may affect how it passes through changes in monetary policy. Separately, we find that our results are not sensitive to the definition of our competition variable. We also estimate the model using the ECB's key interest rates themselves, rather than the money market rate. We show that our results for the impact of impairment on pass-through are robust to inclusion or omission of sets of the bank-specific characteristics. We also estimate the model using pooled OLS with year and country-year fixed effects to address unobserved macroeconomic factors.

\subsection{Results}

In Table 1, we provides estimates of the pass-through equation. In each specification, the assumption of a lagged dependent variable appears to be justified. In column (1), we estimate equation (8) with no bank-specific balance sheet variables: this specification outlines the coefficients on the immediate pass-through, and the long-run elasticity, of the money market rate to the lending rate in the absence of any bank-specific factors. We find that 71.5 per cent of a change in the money market rate is passed through immediately to the lending rate. Following equation (10), we find also that 76 per cent is passed through in the long run. This implies that long-run pass-through in our sample is incomplete, supporting our relaxation of the assumption of a one-to-one long run relationship between the money market rate and the lending rate. We find the expected positive coefficients on the measures of unemployment and inflation in column (1) and throughout.

In column (2), we include our measures of size, liquidity, market concentration and balance sheet 
impairment, interacted fully with the components of immediate and long-run pass-through. We find that bank size appears not to have a significant impact on immediate pass-through, but does improve long-run pass-through. Looking at liquidity, it appears that more liquid banks pass-through more in both the short run and long run. A one percentage point increase in the liquidity ratio improves immediate pass-through by 0.5 percentage points. Greater market concentration appears to result in higher levels of interest rates but not to have an impact on immediate pass-through.

Consistent with our theoretical predictions, we find that immediate pass-through is decreasing in the impairment ratio. A one percentage point increase in the impairment ratio lowers immediate passthrough by 3.7 percentage points. We also find that an elevated impairment ratio results in higher levels of interest rates. In column (3), we include the sovereign bond yields to address the sovereign banking nexus. We find a positive coefficient on yields, implying that sovereign stress does result in higher lending rates. In column (4), we specify the sovereign channel in a different manner, allowing sovereign yields to affect pass-through. We find no significant impact on immediate pass-through, although we do observe an intuitive negative coefficient. The interactions with the components of the long run pass-through imply a level effect from sovereign bond yields, consistent with the findings of column (3).

Hereafter, we take column (3) to be our main specification. Based on the results from this specification, we find that the pass-through coefficient drops from 84 per cent in the absence of impaired loans to 62 per cent for a bank with the mean impairment ratio. We cannot reject the hypothesis that banks with an impairment ratio of 17 per cent or greater do not pass through changes in money market rates at all.

In Table 2 we examine whether the effect of impairments on pass-through is symmetric for rising and falling money market rates ${ }^{5}$. A literature has grown following Peltzman (2000) to test symmetry of pass-through, with asymmetry frequently being motivated by market power. As a result of the cost of balance sheet impairment, banks may be more willing to pass through increases in their funding costs than decreases. To test for this, we interact a dummy variable for the sign of the change in the money market rate with the rate change and with the interactions of the bank characteristics and the rate change. We find that the impairment ratio lowers the pass-through coefficient when the rate is falling. However, we find that pass-through is increasing in the impairment ratio when Eonia is increasing. A one percentage point increase in the impairment ratio increases pass-through by 7 percentage points in this case. We thus find an asymmetric effect of balance sheet impairment on pass-through based on the direction of the change in bank funding cost. We also cannot reject the hypothesis of complete immediate pass-through of money market rate increases for banks with an impairment ratio of 12 per cent or more.

\footnotetext{
${ }^{5}$ The full results from this specification are available in Table 3 of the Web Appendix.
} 
In Table 3 we introduce measures of bank credit risk to our baseline model to investigate whether our results may be affected by funding premia for certain banks. Elevated levels of CDS spreads would indicate that a bank is judged to be risky by the market and would likely face funding premia, which could plausibly affect its lending rate. These premia are unlikely to be constant through time and thus would affect our results if they were to occur at a period of diminished pass-through. In column (1), we thus include a triple interaction of the CDS spread with the impairment ratio and change in the money market rate. We find that our previous results remain robust, with pass-through decreasing significantly in the impairment ratio. We also do not find any evidence for a differential effect for banks which are deemed to be riskier by the market. In column (2), we also include the main effect of the credit risk measure and interact this with the change in the money market rate. We find that banks with higher CDS spreads have higher lending rates. We do not find any significant direct effect from CDS spreads to immediate pass-through, although it is intuitive that the sign of the coefficient is negative. We again find evidence for the effect of the balance sheet on pass-through, with the interaction of the impairment ratio on pass-through remaining robust. As in column (1), we find that the triple interaction of CDS spreads with impairments and the change in the money market rate is not statistically significant. From this we conclude that the balance sheet impairment is not being driven by market perceptions of banks' riskiness, which could result in funding premia.

\subsection{Robustness Checks}

In Appendix Table 1, we specify the monetary policy variable in the pass-through model in terms of Eonia and the ECB's key interest rates: the interest rate on Main Refinancing Operations and the interest rate on the Deposit Facility. We find that the results are not sensitive to the choice of monetary policy variable. The magnitude of the impairment effect on immediate pass-through is similar for Eonia and the MRO, at -3.4 percentage points and -3.5 percentage points, respectively. The effect is slightly larger for the DFR, at -4.8 percentage points for a one percentage point increase in the impairment ratio.

Appendix Table 2 specifies the measure of balance sheet impairment in terms of the NPL ratio as well as the impairment ratio. Our finding of a negative impact of balance sheet impairment on pass-through is robust to specifying the balance sheet measure using the NPL ratio. The impact of non-performing loans on pass-through is negative and significant, as is expected, but the magnitude of the effect is smaller than with the impairment ratio. A one percentage point increase in the NPL ratio lowers pass-through by 2.3 percentage points, compared with the 3.4 percentage point decrease for an equivalent increase in the impairment ratio. It is likely that the impairment effect is underestimated when using the NPL ratio because the NPL ratio mismeasures the costliness of balance sheet 
impairment, the key channel through which non-performing loans should affect loan pricing.

In Appendix Table 6, we include the ratio of non-financial private sector deposits to total liabilities to test whether banks with greater stability of their funding structure have greater pass-through to their lending rates. We find no evidence of a significant effect of the deposit share on immediate passthrough, but we do find that banks with more stable funding have lower lending rates. The coefficient on the impairment effect is stable across these specifications. In Table 7, we replace the Herfindahl measure of concentration in the banking sector with a measure based on the asset shares of the top five credit institutions in each country. Our results are not sensitive to this change. Market concentration continues to be associated with higher lending rates, while our results on the impact of impairments on immediate pass-through remain robust.

In Appendix Table 8, we show that coefficient on the interaction of the impairment ratio with immediate pass-through is stable across specifications in which we iteratively add the liquidity, size and concentration measures to the equation. In Table 9, we re-run our main specification as a pooled OLS estimation. In column (2) we include individual fixed effects, in column (3) we include year fixed effects to capture common macroeconomic shocks, while in column (4) we include country-year fixed effects to account for unobserved macroeconomic factors. We thus account for possible heterogeneity in demand facing banks across the sample by country and time, which possibly could have an impact on loan pricing, allowing us more cleanly to identify how a bank's own balance sheet may affect their loan pricing. Our key result is unchanged across these specifications: greater impairment of bank balance sheet weakens pass-through to lending rates. Finally, in Table 10, we further address the issue of credit demand through specificiations of the macroeconomic variables. We include the sovereign bond yield, unemployment rate and inflation rate measures in levels, changes and both levels and changes. The balance sheet effect is robust to these specifications. 
Table 1: Main specifications

\begin{tabular}{|c|c|c|c|c|}
\hline & (1) & $(2)$ & (3) & (4) \\
\hline$\overline{\Delta i r_{t-1}}$ & $\begin{array}{c}-0.259^{* * *} \\
(0.012)\end{array}$ & $\begin{array}{c}-0.239 * * * \\
(0.013)\end{array}$ & $\begin{array}{c}-0.237^{* * *} \\
(0.013)\end{array}$ & $\begin{array}{l}-0.237^{* * *} \\
(0.013)\end{array}$ \\
\hline$\Delta$ eonia $_{t}$ & $\begin{array}{l}0.715^{* * *} \\
(0.037)\end{array}$ & $\begin{array}{l}0.722^{* * *} \\
(0.116)\end{array}$ & $\begin{array}{l}0.693^{* * *} \\
(0.116)\end{array}$ & $\begin{array}{l}0.698^{* * *} \\
(0.157)\end{array}$ \\
\hline eonia $_{t-1}$ & $\begin{array}{l}0.176^{* * *} \\
(0.009)\end{array}$ & $\begin{array}{l}0.077^{* * *} \\
(0.024)\end{array}$ & $\begin{array}{l}0.075^{* * *} \\
(0.024)\end{array}$ & $\begin{array}{c}0.002 \\
(0.039)\end{array}$ \\
\hline$i r_{t-1}$ & $\begin{array}{l}-0.233^{* * *} \\
(0.010)\end{array}$ & $\begin{array}{l}-0.122^{* * *} \\
(0.022)\end{array}$ & $\begin{array}{l}-0.118^{* * *} \\
(0.022)\end{array}$ & $\begin{array}{l}-0.126^{* * *} \\
(0.023)\end{array}$ \\
\hline $\operatorname{Her} f_{t-1}$ & & $\begin{array}{r}0.018^{*} \\
(0.010)\end{array}$ & $\begin{array}{l}0.026^{* * *} \\
(0.010)\end{array}$ & $\begin{array}{l}0.033^{* * *} \\
(0.010)\end{array}$ \\
\hline Size $_{t-1}$ & & $\begin{array}{r}-0.072 \\
(0.113)\end{array}$ & $\begin{array}{c}-0.081 \\
(0.113)\end{array}$ & $\begin{array}{c}-0.084 \\
(0.113)\end{array}$ \\
\hline Liquidity $_{t-1}$ & & $\begin{array}{l}0.007^{* * * *} \\
(0.002)\end{array}$ & $\begin{array}{l}0.007^{* * * *} \\
(0.002)\end{array}$ & $\begin{array}{l}0.007 * * * \\
(0.002)\end{array}$ \\
\hline$i m p_{t-1}$ & & $\begin{array}{l}0.015^{* *} \\
(0.006)\end{array}$ & $\begin{array}{l}0.020^{* * *} \\
(0.006)\end{array}$ & $\begin{array}{l}0.020^{* * *} \\
(0.006)\end{array}$ \\
\hline $\operatorname{Herf}_{t-1} \times \Delta$ eonia ${ }_{t}$ & & $\begin{array}{r}-0.001 \\
(0.007)\end{array}$ & $\begin{array}{c}0.000 \\
(0.007)\end{array}$ & $\begin{array}{c}0.001 \\
(0.007)\end{array}$ \\
\hline $\operatorname{Her} f_{t-1} \times$ eonia $_{t-1}$ & & $\begin{array}{r}0.002^{*} \\
(0.001)\end{array}$ & $\begin{array}{l}0.003^{*} \\
(0.001)\end{array}$ & $\begin{array}{l}0.003^{* *} \\
(0.001)\end{array}$ \\
\hline $\operatorname{Her} f_{t-1} \times i r_{t-1}$ & & $\begin{array}{l}-0.005^{* * *} \\
(0.002)\end{array}$ & $\begin{array}{l}-0.006^{* * *} \\
(0.002)\end{array}$ & $\begin{array}{l}-0.007^{* * *} \\
(0.002)\end{array}$ \\
\hline Size $_{t-1} \times \Delta$ eonia $_{t}$ & & $\begin{array}{c}0.006 \\
(0.064)\end{array}$ & $\begin{array}{c}0.010 \\
(0.064)\end{array}$ & $\begin{array}{l}0.009 \\
(0.064)\end{array}$ \\
\hline Size $_{t-1} \times$ eonia $_{t-1}$ & & $\begin{array}{l}0.050^{* * *} \\
(0.014)\end{array}$ & $\begin{array}{l}0.044^{* * *} \\
(0.014)\end{array}$ & $\begin{array}{l}0.042^{* * *} \\
(0.014)\end{array}$ \\
\hline Size $_{t-1} \times i r_{t-1}$ & & $\begin{array}{l}-0.031^{* *} \\
(0.015)\end{array}$ & $\begin{array}{r}-0.027^{*} \\
(0.015)\end{array}$ & $\begin{array}{c}-0.022 \\
(0.015)\end{array}$ \\
\hline Liquidity $_{t-1} \times \Delta$ eonia $_{t}$ & & $\begin{array}{r}0.005^{*} \\
(0.003)\end{array}$ & $\begin{array}{r}0.005^{*} \\
(0.003)\end{array}$ & $\begin{array}{l}0.004 \\
(0.003)\end{array}$ \\
\hline Liquidity $_{t-1} \times$ eonia $_{t-1}$ & & $\begin{array}{l}0.002^{* * * *} \\
(0.001)\end{array}$ & $\begin{array}{l}0.002^{* * *} \\
(0.001)\end{array}$ & $\begin{array}{l}0.002^{* * *} \\
(0.001)\end{array}$ \\
\hline Liquidity $_{t-1} \times i r_{t-1}$ & & $\begin{array}{l}-0.002^{* * *} \\
(0.001)\end{array}$ & $\begin{array}{l}-0.002^{* * *} \\
(0.001)\end{array}$ & $\begin{array}{l}-0.002^{* * *} \\
(0.001)\end{array}$ \\
\hline$i m p_{t-1} \times \Delta e o n i a_{t}$ & & $\begin{array}{l}-0.037^{* * *} \\
(0.010)\end{array}$ & $\begin{array}{l}-0.034^{* * *} \\
(0.010)\end{array}$ & $\begin{array}{l}-0.030^{* * *} \\
(0.011)\end{array}$ \\
\hline$i m p_{t-1} \times$ eonia $a_{t-1}$ & & $\begin{array}{r}-0.001 \\
(0.002)\end{array}$ & $\begin{array}{r}-0.002 \\
(0.002)\end{array}$ & $\begin{array}{r}-0.003 \\
(0.002)\end{array}$ \\
\hline$i m p_{t-1} \times i r_{t-1}$ & & $\begin{array}{l}-0.002^{* *} \\
(0.001)\end{array}$ & $\begin{array}{l}-0.003^{* * *} \\
(0.001)\end{array}$ & $\begin{array}{l}-0.003^{* * *} \\
(0.001)\end{array}$ \\
\hline$G B_{t}$ & & & $\begin{array}{l}0.016^{* * *} \\
(0.004)\end{array}$ & $\begin{array}{l}-0.016 \\
(0.014)\end{array}$ \\
\hline$G B_{t} \times \Delta$ eonia $_{t}$ & & & & $\begin{array}{r}-0.008 \\
(0.026)\end{array}$ \\
\hline$G B_{t} \times$ eonia $_{t-1}$ & & & & $\begin{array}{l}0.017^{* *} \\
(0.007)\end{array}$ \\
\hline$G B_{t} \times i r_{t-1}$ & & & & $\begin{array}{r}0.004^{*} \\
(0.002)\end{array}$ \\
\hline$U n_{t}$ & $\begin{array}{l}0.032^{* * *} \\
(0.003)\end{array}$ & $\begin{array}{l}0.029 * * * \\
(0.004)\end{array}$ & $\begin{array}{l}0.022^{* * * *} \\
(0.004)\end{array}$ & $\begin{array}{l}0.025^{* * *} \\
(0.004)\end{array}$ \\
\hline$H I C P_{t}$ & $\begin{array}{l}0.052^{* * *} \\
(0.006)\end{array}$ & $\begin{array}{l}0.051^{* * *} \\
(0.007)\end{array}$ & $\begin{array}{l}0.047^{* * *} \\
(0.007)\end{array}$ & $\begin{array}{l}0.042^{* * *} \\
(0.007)\end{array}$ \\
\hline Constant & $\begin{array}{l}0.401^{* * *} \\
(0.033)\end{array}$ & $\begin{array}{c}0.086 \\
(0.102)\end{array}$ & $\begin{array}{c}0.035 \\
(0.103)\end{array}$ & $\begin{array}{c}0.094 \\
(0.107)\end{array}$ \\
\hline Fixed effects & Bank & Bank & Bank & Bank \\
\hline $\mathrm{N}$ & 5,944 & 5,350 & 5,350 & 5,350 \\
\hline
\end{tabular}

Notes: Models (1) - (4) use the FE estimator. Standard errors are in parentheses and significance level displayed as ${ }^{*} \mathrm{p}<0.1 ;{ }^{* *} \mathrm{p}<0.05 ;{ }^{* * *} \mathrm{p}<0.01$ 
Table 2: Asymmetric effect of impairment on pass-through

\begin{tabular}{|c|c|}
\hline & (1) \\
\hline$\overline{\Delta e o n i a_{t}^{\text {neg }} \times \Delta \text { eonia }}$ & $\begin{array}{l}0.923^{* * *} \\
(0.141)\end{array}$ \\
\hline$\Delta e o n i a_{t}^{p o s} \times \Delta$ eonia $_{t}$ & $\begin{array}{c}-0.407 \\
(0.366)\end{array}$ \\
\hline$\Delta \operatorname{eonia}_{t}^{\text {neg }} \times \operatorname{Herf}_{t-1} \times \Delta$ eonia $_{t}$ & $\begin{array}{c}0.003 \\
(0.009)\end{array}$ \\
\hline$\Delta e o n i a_{t}^{\text {pos }} \times \operatorname{Herf}_{t-1} \times \Delta e o n i a_{t}$ & $\begin{array}{c}-0.015 \\
(0.023)\end{array}$ \\
\hline$\Delta e \operatorname{onia}_{t}^{\text {neg }} \times$ Size $_{t-1} \times \Delta e o n i a_{t}$ & $\begin{array}{c}-0.042 \\
(0.078)\end{array}$ \\
\hline$\Delta e \operatorname{onia}_{t}^{\text {pos }} \times$ Size $_{t-1} \times \Delta e o n i a_{t}$ & $\begin{array}{c}0.313 \\
(0.200)\end{array}$ \\
\hline$\Delta$ eonia $_{t}^{n e g} \times$ Liquidity $_{t-1} \times \Delta$ eonia $_{t}$ & $\begin{array}{c}0.004 \\
(0.003)\end{array}$ \\
\hline$\Delta$ eonia $_{t}^{\text {pos }} \times$ Liquidity $_{t-1} \times \Delta$ eonia $_{t}$ & $\begin{array}{c}0.005 \\
(0.008)\end{array}$ \\
\hline$\Delta e o n i a_{t}^{\text {neg }} \times i m p_{t-1} \times \Delta e$ onia $_{t}$ & $\begin{array}{l}-0.054^{* * *} \\
(0.013)\end{array}$ \\
\hline 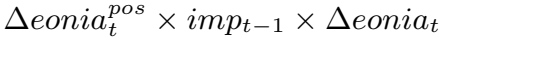 & $\begin{array}{l}0.070^{* *} \\
(0.027)\end{array}$ \\
\hline $\begin{array}{l}\text { Fixed effects } \\
\text { Other controls }\end{array}$ & $\begin{array}{l}\text { Bank } \\
\text { Yes }\end{array}$ \\
\hline $\mathrm{N}$ & 5,350 \\
\hline
\end{tabular}
significance level displayed as ${ }^{*} \mathrm{p}<0.1 ;{ }^{* *} \mathrm{p}<0.05 ;{ }^{* * *} \mathrm{p}<0.01$ 
Table 3: Impact of bank credit risk on pass-through

\begin{tabular}{|c|c|c|}
\hline & (1) & $(2)$ \\
\hline$\Delta i r_{t-1}$ & $\begin{array}{c}-0.212^{* * *} \\
(0.016)\end{array}$ & $\begin{array}{c}-0.210^{* * * *} \\
(0.016)\end{array}$ \\
\hline$i m p_{t-1}$ & $\begin{array}{l}0.037^{* * *} \\
(0.007)\end{array}$ & $0.050^{* * *}$ \\
\hline$C D S_{t}$ & & $\begin{array}{l}0.037^{* * *} \\
(0.007)\end{array}$ \\
\hline$\Delta$ eonia $_{t}$ & $\begin{array}{l}0.827^{* * *} \\
(0.145)\end{array}$ & $\begin{array}{l}0.804^{* * *} \\
(0.160)\end{array}$ \\
\hline eonia $_{t-1}$ & $\begin{array}{c}0.026 \\
(0.029)\end{array}$ & $\begin{array}{l}0.082^{* * *} \\
(0.031)\end{array}$ \\
\hline$i r_{t-1}$ & $\begin{array}{c}-0.062^{* *} \\
(0.029)\end{array}$ & $\begin{array}{c}-0.075^{* * *} \\
(0.029)\end{array}$ \\
\hline$C D S_{t} \times \Delta$ eonia $t$ & & $\begin{array}{c}-0.022 \\
(0.033)\end{array}$ \\
\hline$i m p_{t-1} \times \Delta e o n i a_{t}$ & $\begin{array}{c}-0.062^{* * *} \\
(0.019)\end{array}$ & $\begin{array}{c}-0.050^{* * *} \\
(0.019)\end{array}$ \\
\hline$i m p_{t-1} \times$ eonia $_{t-1}$ & $\begin{array}{l}0.012^{* * *} \\
(0.003)\end{array}$ & $\begin{array}{c}0.006^{*} \\
(0.004)\end{array}$ \\
\hline$i m p_{t-1} \times i r_{t-1}$ & $\begin{array}{c}-0.007^{* * *} \\
(0.001)\end{array}$ & $\begin{array}{c}-0.007^{* * *} \\
(0.001)\end{array}$ \\
\hline$i m p_{t-1} \times C D S_{t} \times \Delta$ eonia $_{t}$ & $\begin{array}{c}0.001 \\
(0.001)\end{array}$ & $\begin{array}{c}0.001 \\
(0.002)\end{array}$ \\
\hline $\begin{array}{l}\text { Fixed effects } \\
\text { Other controls }\end{array}$ & $\begin{array}{c}\text { Bank } \\
\text { Yes }\end{array}$ & $\begin{array}{c}\text { Bank } \\
\text { Yes }\end{array}$ \\
\hline $\mathrm{N}$ & 3,451 & 3,451 \\
\hline
\end{tabular}
and significance level displayed as ${ }^{*} \mathrm{p}<0.1 ;{ }^{* *} \mathrm{p}<0.05 ;{ }^{* * *} \mathrm{p}<0.01$. CDS unit $=100 \mathrm{bp}$. 


\section{$5 \quad$ Excess non-performing loans}

Thus far, we have considered the impact of impaired balance sheets on pass-through solely through the lens of the impairment ratio. However, it is possible for there to be an additional channel through which non-performing loans can affect pass-through. Having an excess of non-performing loans over impaired loans may lead a forward-looking bank to expect to realise impairment charges against these loans, in whole or in part. The NPL ratio thus can be thought of as nesting two components: the actual realisation of costly balance sheet impairment (the impairment ratio) and the expected additional cost which will arise from future impairment. As we have argued in Section 4.1, to cleanly identify the balance sheet impairment effect, one must focus on the former. However, the latter may also affect loan pricing. In this section, we thus examine whether excess non-performing loans affect pass-through, controlling for the direct balance sheet impairment effect.

We refer to the difference between the NPL ratio and the impairment ratio as the NPL gap. The left-hand panel of Figure 3 shows a scatter plot of the NPL gap against the NPL ratio. There is a positive correlation between the two measures so that the higher the NPL ratio, the greater the share of these loans against which an impairment charge has not yet been realised. The mean value of the NPL gap is 3.3 percentage points and the gap is almost always positive ${ }^{6}$. In the right-hand panel of Figure 3, we show simple linear fits of the cumulative change in lending rate in our time period against each of the impairment ratio and the NPL gap. Banks with the healthiest balance sheets have lowered their lending rates by approximately 3 percentage points between January 2008 and June 2014, representing a considerable degree of pass-through of the change in Eonia over the period. The data show that pass-through is decreasing in both the impairment ratio and the NPL gap, motivating further investigation of whether the NPL gap affects pass-through in our full mode, controlling for the direct impairment effect.

In Table 4, we include the NPL gap measure as an additional bank-specific characteristic in our main specification ${ }^{7}$. In the first column, we include only the macroeconomic variables, the bank-specific impairment ratio and the NPL gap. The main effect of the impairment ratio is no longer significant, but the main effect of the NPL gap is positive and highly significant. This indicates that banks with a proliferation of excess non-performing loans have higher interest rates. We find that the effect of the impairment ratio on immediate pass-through is robust to adding the NPL gap to the model, and of similar magnitude to the model in Table 1. The NPL gap also has a significant and negative impact on immediate pass-through, controlling for the direct impairment effect. A one percentage point increase in excess non-performing loans lowers immediate pass-through by 2.2 percentage points. These results

\footnotetext{
${ }^{6}$ As can be seen from Table 5, the NPL gap is not exclusively positive: in some instances banks have precautionarily taken impairment charges in excess of their current NPL ratio.

${ }^{7}$ The full results from this specification are available in Table 5 of the Web Appendix.
} 
suggest that the weakening of pass-through to lending rates caused by balance sheet impairment which we have identified is exacerbated by the presence of excess non-performing loans. We show across the columns of Table 4 that this finding is robust to the addition of the other balance sheet explanatory variables.

Taking the results of this specification, we are able to decompose the contributions of the explanatory variables to both immediate and long-run passthrough. In Figure 4 we split the sample by vulnerable and non-vulnerable country groups. We plot the fitted values for the pass-through coefficients in the black lines and the contributions of the explanatory variables in the bars. In the left panel, the pass-through coefficient declines slightly throughout the sample for banks in non-vulnerable countries. Pass-through falls to a much greater extent in the vulnerable countries (right panel), declining by approximately 25 percentage points to 50 per cent by 2014, before increasing somewhat in 2016. The blue bars depict the positive contribution of bank liquidity to pass-through in both groups throughout. The red bars show the negative impact of the impairment ratio to pass-through. This impairment effect holds across country groups, albeit with greater magnitude in the vulnerable countries. Excess non-performing loans also contribute to falling pass-through, as shown in the purple bars. Toward the end of the sample, the problem of excess NPLs is mitigated somewhat in the vulnerable countries, contributing to some improvement in immediate pass-through.

Figure 5 shows the decomposition of the contributions to long run pass-through. Pass-through is incomplete and falling through time in both areas, although the decline is more pronounced in the vulnerable countries. Notably, competition effects have a larger impact on long-run pass-through than immediate pass-through. Market concentration weakens the long run elasticity of the lending rate to the money market rate in both vulnerable and non-vulnerable countries, but relatively by more in the vulnerable countries. The negative competition effect also grows throughout the time period in the vulnerable countries, intuitively reflecting the changes in the competitive backdrop of banking markets in Europe since the Global Financial Crisis. As found above in terms of immediate pass-through, the impairment ratio makes the largest negative contribution to long run pass-through in the vulnerable countries. The NPL gap also lowers long run pass-through in both country groups, but by less than the competition effect. 
Table 4: Impact of excess non-performing loans

\begin{tabular}{|c|c|c|c|c|}
\hline & (1) & $(2)$ & (3) & (4) \\
\hline$\Delta e$ onia $_{t}$ & $\begin{array}{l}0.838^{* * *} \\
(0.055)\end{array}$ & $\begin{array}{l}0.706^{* * *} \\
(0.092)\end{array}$ & $\begin{array}{l}0.715^{* * *} \\
(0.103)\end{array}$ & $\begin{array}{l}0.714^{* * *} \\
(0.116)\end{array}$ \\
\hline eonia $_{t-1}$ & $\begin{array}{l}0.162^{* * *} \\
(0.011)\end{array}$ & $\begin{array}{l}0.118^{* * *} \\
(0.020)\end{array}$ & $\begin{array}{l}0.086^{* * *} \\
(0.021)\end{array}$ & $\begin{array}{l}0.078^{* * *} \\
(0.024)\end{array}$ \\
\hline$i r_{t-1}$ & $\begin{array}{l}-0.196^{* * *} \\
(0.012)\end{array}$ & $\begin{array}{l}-0.162^{* * *} \\
(0.019)\end{array}$ & $\begin{array}{l}-0.144^{* * *} \\
(0.020)\end{array}$ & $\begin{array}{l}-0.116^{* * *} \\
(0.022)\end{array}$ \\
\hline$i m p_{t-1}$ & $\begin{array}{c}0.006 \\
(0.007)\end{array}$ & $\begin{array}{r}-0.001 \\
(0.007)\end{array}$ & $\begin{array}{r}-0.001 \\
(0.007)\end{array}$ & $\begin{array}{r}-0.003 \\
(0.007)\end{array}$ \\
\hline $\operatorname{nplgap}_{t-1}$ & $\begin{array}{l}0.061^{* * *} \\
(0.010)\end{array}$ & $\begin{array}{l}0.060^{* * *} \\
(0.010)\end{array}$ & $\begin{array}{l}0.062^{* * *} \\
(0.010)\end{array}$ & $\begin{array}{l}0.060^{* * *} \\
(0.010)\end{array}$ \\
\hline$i m p_{t-1} \times \Delta$ eonia $t_{t}$ & $\begin{array}{c}-0.023^{* *} \\
(0.011)\end{array}$ & $\begin{array}{c}-0.025^{* *} \\
(0.011)\end{array}$ & $\begin{array}{c}-0.025^{* *} \\
(0.011)\end{array}$ & $\begin{array}{c}-0.025^{* *} \\
(0.011)\end{array}$ \\
\hline$i m p_{t-1} \times$ eonia $a_{t-1}$ & $\begin{array}{r}-0.003 \\
(0.002)\end{array}$ & $\begin{array}{r}-0.003 \\
(0.002)\end{array}$ & $\begin{array}{r}-0.002 \\
(0.002)\end{array}$ & $\begin{array}{r}-0.003 \\
(0.002)\end{array}$ \\
\hline$i m p_{t-1} \times i r_{t-1}$ & $\begin{array}{r}-0.001 \\
(0.001)\end{array}$ & $\begin{array}{c}0.001 \\
(0.001)\end{array}$ & $\begin{array}{c}0.000 \\
(0.001)\end{array}$ & $\begin{array}{c}0.001 \\
(0.001)\end{array}$ \\
\hline nplgap $_{t-1} \times \Delta$ eonia $_{t}$ & $\begin{array}{r}-0.022^{*} \\
(0.012)\end{array}$ & $\begin{array}{r}-0.022^{*} \\
(0.012)\end{array}$ & $\begin{array}{r}-0.022^{*} \\
(0.012)\end{array}$ & $\begin{array}{r}-0.022^{*} \\
(0.012)\end{array}$ \\
\hline nplgap $_{t-1} \times$ eonia $_{t-1}$ & $\begin{array}{l}0.006^{* * *} \\
(0.002)\end{array}$ & $\begin{array}{l}0.006^{* * *} \\
(0.002)\end{array}$ & $\begin{array}{l}0.007^{* * *} \\
(0.002)\end{array}$ & $\begin{array}{l}0.006^{* * *} \\
(0.002)\end{array}$ \\
\hline$n p l g a p_{t-1} \times i r_{t-1}$ & $\begin{array}{c}-0.011^{* * *} \\
(0.002)\end{array}$ & $\begin{array}{c}-0.010^{* * *} \\
(0.002)\end{array}$ & $\begin{array}{c}-0.011^{* * *} \\
(0.002)\end{array}$ & $\begin{array}{c}-0.010^{* * *} \\
(0.002)\end{array}$ \\
\hline Fixed effects & Bank & Bank & Bank & Bank \\
\hline Liquidity & No & Yes & Yes & Yes \\
\hline Bank size & No & No & Yes & Yes \\
\hline Market concentration & No & No & No & Yes \\
\hline Other controls & Yes & Yes & Yes & Yes \\
\hline $\mathrm{N}$ & 5,658 & 5,350 & 5,350 & 5,350 \\
\hline
\end{tabular}

Notes: Models (1) - (4) use the FE estimator. Standard errors are in parentheses and significance level displayed as ${ }^{*} \mathrm{p}<0.1 ;{ }^{* *} \mathrm{p}<0.05 ;{ }^{* * *} \mathrm{p}<0.01$

Figure 3: NPL Gap and Pass-through
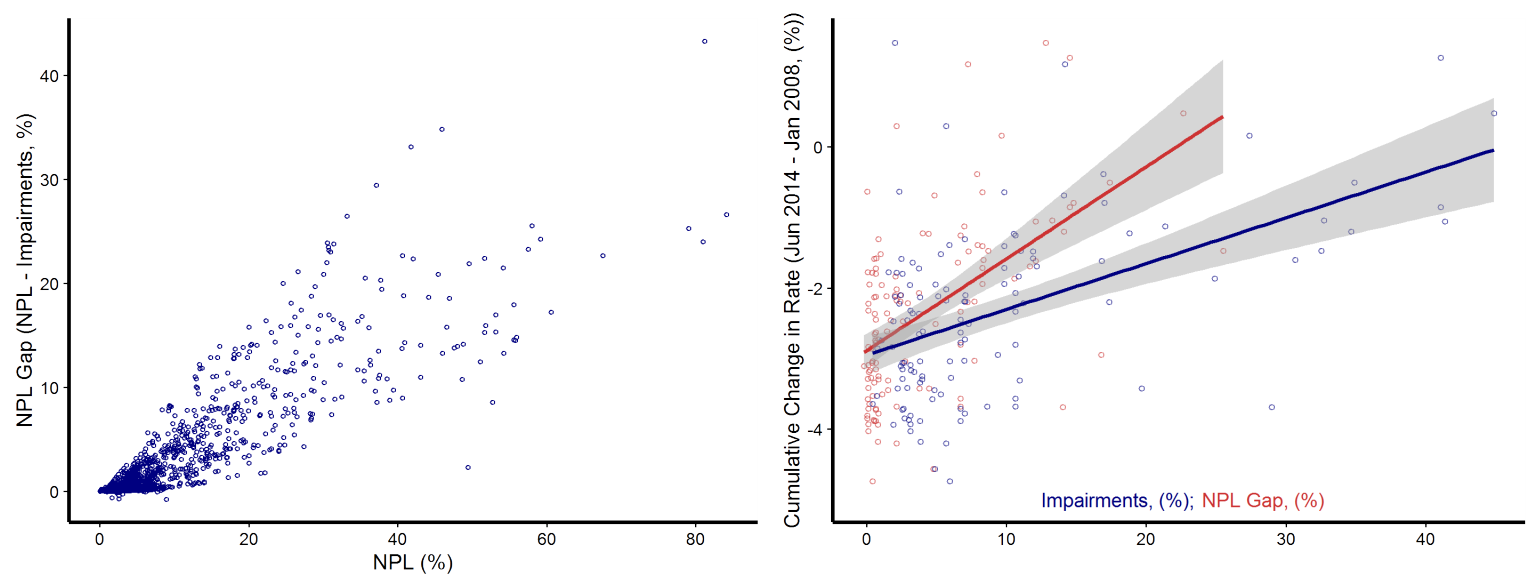

Notes: The left-hand panel of Figure 3 shows a scatter plot of the NPL gap, the excess of the NPL ratio over the impairment ratio against the NPL ratio. The right-hand panel shows a scatter plot and fitted lines with confidence intervals of the cumulative changes in individual banks' lending rates against their impairment ratios (in blue) and the NPL gap (in red). 
Figure 4: Determinants of Short Run Pass-through
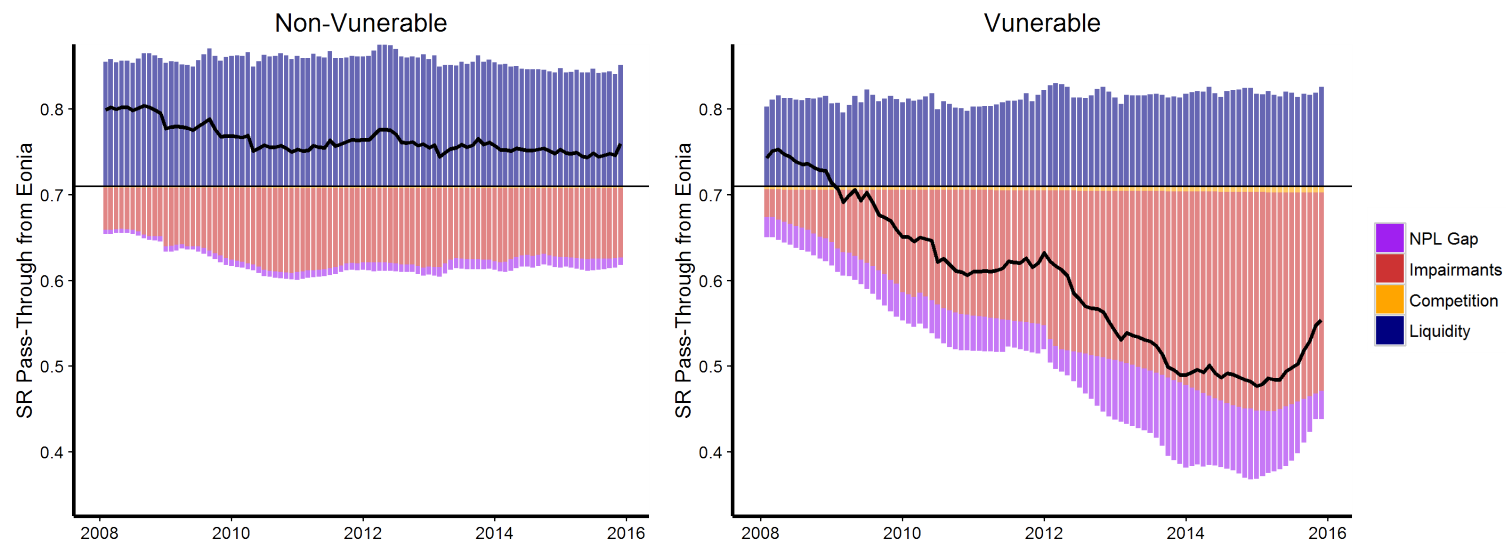

Notes: Figure 4 shows the immediate pass-through coefficient through time (black line) for banks in vulnerable and non-vulnerable European countries. The contributions of the NPL gap, impairment ratio, market concentration and bank liquidity are included in the coloured bars.

Figure 5: Determinants of Long Run Pass-through
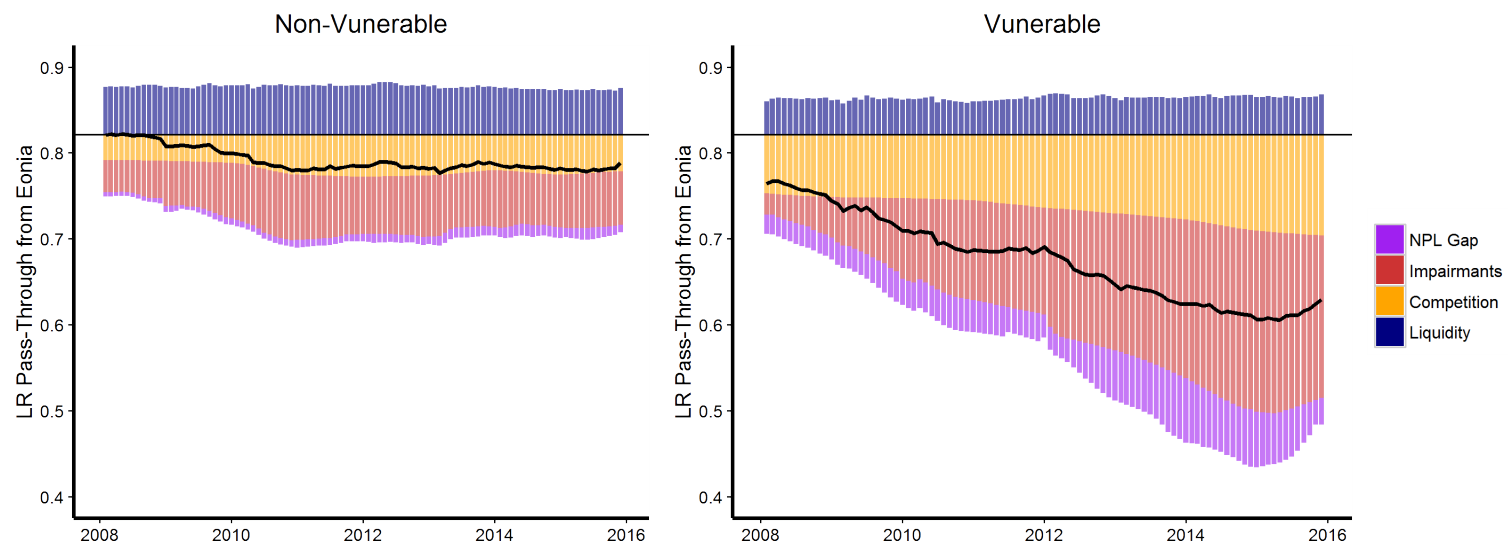

Notes: Figure 5 shows the long run pass-through coefficient through time (black line) for banks in vulnerable and non-vulnerable European countries. The contributions of the NPL gap, impairment ratio, market concentration and bank liquidity are included in the coloured bars. 


\section{Conclusion}

The vast majority of European firms (99.8 per cent) are small and medium enterprises, responsible for over 70 per cent of employment making them central to the economic growth of the euro area ${ }^{8}$. Unlike their US counterparts, their sources of finance are more limited, relying heavily on bank debt to fund investment. To assess the impact of monetary policy decisions on this group, it is paramount to examine the credit channel, whereby credit supply and price may respond strongly to shifts in the policy rate. Euro area pass-through has shifted from being relatively homogenous to fragmented and incomplete since the financial crisis. While sovereign risk plays a role, the direct implications for bank profitability from distressed lending hamper banks ability to supply credit and lower loan pricing in response to reductions in the policy rate.

This paper derives a parsimonious model decomposing the drivers of loan pricing into the contribution of the policy rate, default risk, loss given default, sovereign bond yield, market concentration and sensitivity of capital to new lending. This allows us to characterise the channels through which asset quality diminishes pass-through of the changes in the policy rate. Using bank level data over the period 2008-2014, we empirically test the implications of the model for both short and long run adjustment of lending rates. Results show that asset quality, measured through a one percentage point increase in the impairment ratio have a significant negative impact, lowering immediate pass-through by 3 per cent. For impairment rates greater than 17 per cent, we find pass-though is not significantly different from zero.

Distressed loan books erode limited bank capital and result in impairments being unable to keep pace with bad loans. To investigate if impairments therefore underestimate the extent of the bad loan problem, we calculate an NPL gap for each bank, as the difference between NPL and impairment ratios. This gap is significant and grows with level of non-performing loans. We find that excess non-performing loans further diminish pass-through to lending rates, controlling for the direct effect of impairments. Further, there is a clear concentration of the NPL gap with the stressed countries and thus these play a key role in explaining the fragmentation of pass-through rates since 2008. This underlines the importance of realisation and resolution of bad loans to lower loan pricing and improve the functioning of euro area credit supply to Europe's heavily bank credit dependent firms.

\footnotetext{
${ }^{8}$ Source: ECB SAFE survey
} 


\section{Appendix}

Proof of Proposition 1: Let $A=1+\gamma f\left(R_{m}\right)+(1-\gamma) h\left(Y_{s}\right)+g\left(R_{m}\right) \cdot \frac{\partial K_{i}}{\partial L_{i}}-P D(1-L G D)$. Then we have

$$
\begin{aligned}
\frac{\partial R_{L}}{\partial P D}=\frac{L G D+\gamma f\left(R_{m}\right)+(1-\gamma) h\left(Y_{s}\right)+g\left(R_{m}\right) \cdot \frac{\partial K_{i}}{\partial L_{i}}}{\left[(1-P D)\left(1-\frac{H}{\epsilon}\right)\right]^{2}}>0 \\
\frac{\partial R_{L}}{\partial H}=\frac{\left(\frac{1}{\epsilon}\right) A}{(1-P D)\left(1-\frac{H}{\epsilon}\right)^{2}}>0 \\
\frac{\partial R_{L}}{\partial L G D}=\frac{P D}{(1-P D)\left(1-\frac{H}{\epsilon}\right)}>0 \\
\frac{\partial R_{L}}{\partial Y_{s}}=\frac{(1-\gamma) h^{\prime}\left(Y_{s}\right)}{(1-P D)\left(1-\frac{H}{\epsilon}\right)}>0 \\
\frac{\partial R_{L}}{\partial\left(\frac{\partial K_{i}}{\partial L_{i}}\right)}=\frac{g\left(R_{m}\right)}{(1-P D)\left(1-\frac{H}{\epsilon}\right)}>0 \\
\frac{\partial R_{L}}{\partial \epsilon}=\frac{-\left(\frac{H}{\epsilon^{2}}\right) A}{(1-P D)\left(1-\frac{H}{\epsilon}\right)^{2}}<0
\end{aligned}
$$

Proof of Proposition 2: The impact of impaired loans on pass-through is given by the cross-partial derivative of equation (7) with respect to the impairment ratio (IMP):

$$
\frac{\partial^{2} R_{L}}{\partial R_{m} \partial I M P_{i}}=\frac{(1-\gamma) g^{\prime}\left(R_{m}\right)}{(1-P D)\left(1-\frac{H}{\epsilon}\right)} \cdot \frac{\partial^{2} K_{i}}{\partial L_{i} \partial I M P_{i}}<0 .
$$

The first term in equation (11) is positive, hence the overall sign is determined by the sign of the cross partial derivative of the bank's capital position with respect to the flow of lending and the impairment ratio of the stock of lending. This must be negative given that the negative impact of the impairments on bank capital is mitigated by the issuance of equity in response to the flow of lending. Equivalently, the positive impact of issuance of equity on the capital position diminishes the greater the realised cost from impairing the bank's non-performing loans. As a result, we have it that the pass-through of changes in the monetary policy rate to changes in the lending rate is weakened the higher the impairment ratio of the bank. 
Table 5: Summary Statistics

\begin{tabular}{llllll}
\hline \hline Variable & Obs. & Mean & St. Dev. & Min. & Max. \\
\hline Impairment Ratio (\%) & 5,350 & 6.5 & 6.7 & 0.5 & 55 \\
NPL Ratio (\%) & 5,350 & 9.9 & 10.7 & 0.5 & 82.5 \\
NPL Gap (pp) & 5,350 & 3.3 & 5.1 & -0.8 & 34.8 \\
Size (€ bn.) & 5,350 & 536.2 & 572.1 & 0.6 & 2249.1 \\
Liquidity (\%) & 5,350 & 26.9 & 13.2 & 0.1 & 86 \\
Market Concentration (\%) & 5,350 & 7.1 & 5 & 1.8 & 21.7 \\
Deposit Share (\%) & 5,350 & 16.9 & 14.3 & 0 & 71.5 \\
CDS Spreads (bp) & 3,451 & 311.3 & 402.8 & 38.4 & 2640.6 \\
EONIA (\%) & 5,350 & 0.8 & 1.2 & 0.1 & 4.3 \\
10 Year Sovereign Yield (\%) & 5,350 & 4.3 & 2.8 & 1.2 & 29.2 \\
Inflation (\%) & 5,350 & 2.1 & 1.2 & -2.5 & 6.1 \\
Unemployment (\%) & 5,350 & 10.1 & 6.1 & 3.4 & 27.9 \\
\hline
\end{tabular}

Table 6: Lending rates by bank characteristic

\begin{tabular}{|c|c|c|c|}
\hline & Quartile & Mean & St. Dev. \\
\hline Total sample & & 4.1 & 1.6 \\
\hline Impairment Ratio & $\begin{array}{l}<\mathrm{p} 25 \\
>\mathrm{p} 75\end{array}$ & $\begin{array}{l}3.6 \\
4.6\end{array}$ & $\begin{array}{l}1.6 \\
1.7\end{array}$ \\
\hline Impairment Ratio (2010:6) & $\begin{array}{l}<\mathrm{p} 25 \\
>\text { p } 75\end{array}$ & $\begin{array}{l}3.1 \\
4.1\end{array}$ & $\begin{array}{l}1.2 \\
1.5\end{array}$ \\
\hline Impairment Ratio (2012:6) & $\begin{array}{l}<\mathrm{p} 25 \\
>\mathrm{p} 75\end{array}$ & $\begin{array}{l}3.1 \\
5.5\end{array}$ & $\begin{array}{l}0.8 \\
1.9\end{array}$ \\
\hline Impairment Ratio (2014:6) & $\begin{array}{l}<\mathrm{p} 25 \\
>\mathrm{p} 75\end{array}$ & $\begin{array}{l}2.7 \\
5\end{array}$ & $\begin{array}{l}0.6 \\
1.6\end{array}$ \\
\hline NPL Ratio & $\begin{array}{l}<\mathrm{p} 25 \\
>\mathrm{p} 75\end{array}$ & $\begin{array}{l}3.6 \\
4.6\end{array}$ & $\begin{array}{l}1.6 \\
1.6\end{array}$ \\
\hline NPL Gap & $\begin{array}{l}<\mathrm{p} 25 \\
>\mathrm{p} 75\end{array}$ & $\begin{array}{l}3.8 \\
4.4\end{array}$ & $\begin{array}{l}1.6 \\
1.6\end{array}$ \\
\hline Size & $\begin{array}{l}<\mathrm{p} 25 \\
>\mathrm{p} 75\end{array}$ & $\begin{array}{l}3.9 \\
3.6\end{array}$ & $\begin{array}{l}1.7 \\
1.4\end{array}$ \\
\hline Liquidity & $\begin{array}{l}<\mathrm{p} 25 \\
>\mathrm{p} 75\end{array}$ & $\begin{array}{l}4.3 \\
3.4\end{array}$ & $\begin{array}{l}1.6 \\
1.5\end{array}$ \\
\hline Market Concentration & $\begin{array}{l}<\mathrm{p} 25 \\
>\text { p } 75\end{array}$ & $\begin{array}{l}3.3 \\
4.7\end{array}$ & $\begin{array}{l}1.3 \\
1.7\end{array}$ \\
\hline Deposit Share & $\begin{array}{l}<\mathrm{p} 25 \\
>\mathrm{p} 75\end{array}$ & $\begin{array}{l}3.6 \\
3.4\end{array}$ & $\begin{array}{l}1.5 \\
1.2\end{array}$ \\
\hline CDS Spreads & $\begin{array}{l}<\mathrm{p} 25 \\
>\mathrm{p} 75\end{array}$ & $\begin{array}{l}3.5 \\
4.8\end{array}$ & $\begin{array}{l}1.7 \\
1.5\end{array}$ \\
\hline
\end{tabular}


Figure 6: Market Concentration and Pass-through
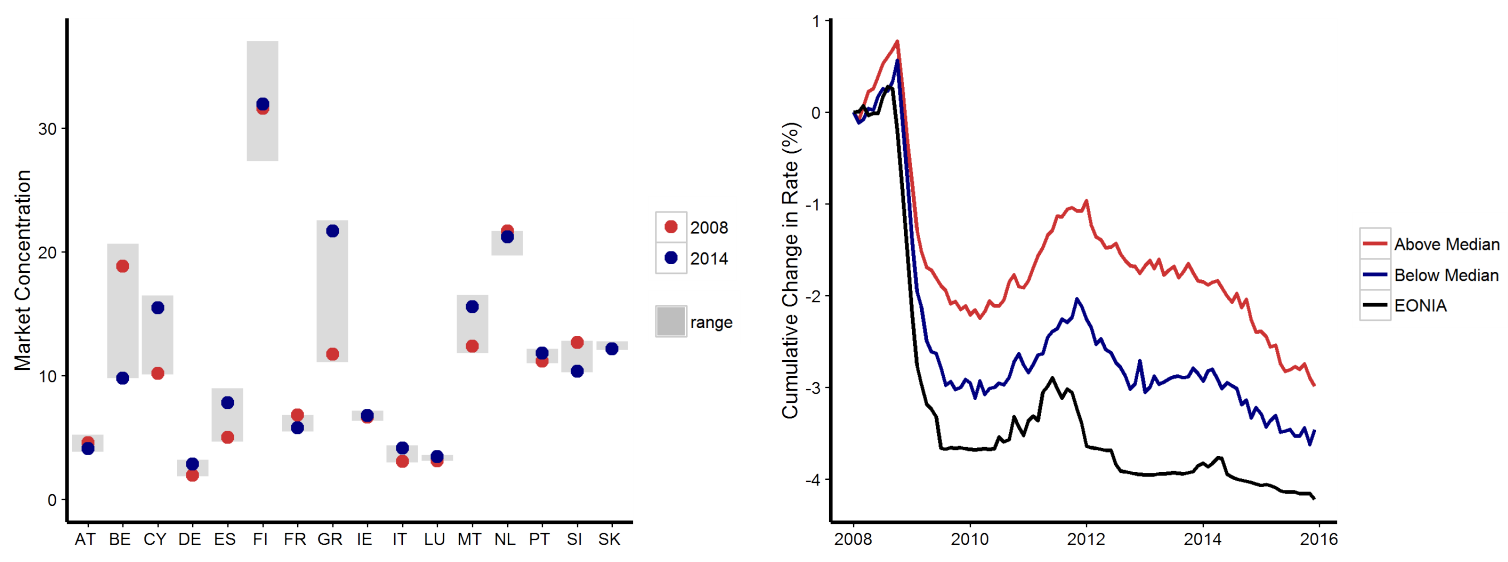

Table 7: Data Description

\begin{tabular}{|c|c|c|}
\hline Variables & Symbols & Description \\
\hline Dependent variable & ir & $\begin{array}{l}\text { Interest rate on loans to euro area non-financial corporations } \\
\text { of up to } € 1 \mathrm{~m} \text { in volume and for up to } 1 \text { year in fixation } \\
\text { (ECB IMIR) }\end{array}$ \\
\hline Monetary policy variables & $\mathrm{mr}$ & $\begin{array}{l}\text { EONIA (DataStream) } \\
\text { Interest rate on Main Refinancing Operations (ECB SDW) } \\
\text { Interest rate on the Deposit Facility (ECB SDW) }\end{array}$ \\
\hline Bank-specific variables & $\mathrm{Z}$ & $\begin{array}{l}\text { Ratio of impaired loans to all loans (SNL Financial) } \\
\text { Ratio of non-performing loans to all loans (SNL Financial) } \\
\text { Size: total assets of bank (SNL Financial) } \\
\text { Liquidity: ratio to total assets of holdings of securities (MFI, } \\
\text { NFC and government) and holdings of loans to MFIs and } \\
\text { to the Eurosystem (ECB IBSI) } \\
\text { Deposit share: Share of non-financial private sector deposits } \\
\text { to total assets (ECB IBSI) } \\
\text { CDS spreads (Bloomberg) }\end{array}$ \\
\hline Country-specific variables & $\mathrm{X}$ & $\begin{array}{l}\text { Herfindahl index for credit institutions' total assets } \\
\text { (ECB SDW) } \\
\text { Share of total assets of top five largest credit institutions } \\
\text { to total assets of banking sector (ECB SDW) } \\
10 \text { year government bond yield (DataStream) } \\
\text { HICP inflation rate (DataStream) } \\
\text { Unemployment rate (DataStream) }\end{array}$ \\
\hline
\end{tabular}

\section{References}

Acharya, Viral V., Björn Imbierowicz, Sascha Steffen, and Daniel Teichmann, "Does Lack of Financial Stability Impair the Transmission of Monetary Policy?, HIT-REFINED Working Paper Series 24, Institute of Economic Research, Hitotsubashi University 2015.

Altavilla, Carlo, Fabio Canova, and Matteo Ciccarelli, "Mending the broken link: heterogeneous bank lending and monetary policy pass-through," Working Paper Series 1978, European Central Bank November 2016.

_, Giacomo Carboni, and Roberto Motto, "Asset Purchase Programmes and Financial Markets: 
Lessons from the Euro Area," Working Paper Series 1864, European Central Bank November 2015.

Aristei, David and Manuela Gallo, "Interest rate pass-through in the Euro area during the financial crisis: A multivariate regime-switching approach," Journal of Policy Modelling, March-April 2014, 36 (2), 273-295.

Avouyi-Dovi, S., Guillaume Horney, and P. Sevestre, "The stability of short-term interest rates pass-through in the euro area during the financial market and sovereign debt crises," Journal of Banking 83 Finance, 2017, 79 (C), 74-94.

Balgova, Maria, Michel Nies, and Alexander Plekhanov, "The Economic Impact of Reducing Non-Performing Loans," European Bank for Reconstruction and Development Working Paper Series, 2016, 193.

Banerjee, Anindya, John W Galbraith, and Juan Dolado, "Dynamic Specification and Linear Transformations of the Autoregressive-Distributed Lag Model," Oxford Bulletin of Economics and Statistics, February 1990, 52 (1), 95-104.

Brei, Michael, Leonardo Gambacorta, and Goetz von Peter, "Rescue packages and bank lending," Journal of Banking \& Finance, 2013, 37 (2), 490-505.

Ciccarelli, M., A. Maddaloni, and J.L. Peydró, "Heterogeneous Transmission Mechanism: Monetary Policy and Financial Fragility in the Eurozone," Economic Policy, 2013, 28, 459-512.

Constâncio, V., "Resolving Europes NPL burden: challenges and benefits," 2017.

Cucinelli, D., "The Impact of Non-Performing Loans on Bank Lending Behaviour: Evidence from the Italian Banking Sector," Eurasian Journal of Business and Economics, 2015, 8, 59-71.

Donnery, Sharon, "Setting the standard: NPL workout in the euro area," 2017.

Freixas, Xavier and Jean-Charles Rochet, Microeconomics of Banking, 2nd Edition, Vol. 1 of MIT Press Books, The MIT Press, 2008.

Gambacorta, Leonardo, "How do banks set interest rates?," European Economic Review, July 2008, 52 (5), 792-819.

_ and Paolo Emilio Mistrulli, "Bank Heterogeneity and Interest Rate Setting: What Lessons Have We Learned since Lehman Brothers?," Journal of Money, Credit and Banking, 06 2014, 46 (4), $753-778$.

Holton, Sarah and Costanza Rodriguez d'Acri, "Jagged cliffs and stumbling blocks: interest rate pass-through fragmentation during the Euro area crisis," Working Paper Series 1850, European Central Bank 2015.

- and Fergal McCann, "Sources of the Small Firm Financing Premium: Evidence from Euro Area Banks," Research Technical Paper, Central Bank of Ireland, 2016, (09/RT/16).

Hristov, K., O. Hulsewig, and T. Wollmerhouser, "Interest Rate Pass-through in the Euro Area during the Global Financial Crisis," Journal of Banking and Finance, 2014, 48, 104-119.

Illes, Anamaria, Marco Lombardi, and Paul Mizen, "Why Did Bank Lending Rates Diverge from Policy Rates aftre the Financial Crisis," BIS Working Paper Series, 2015, No. 486.

Jiménez, Gabriel, Steven Ongena, José-Luis Peydró, and Saurina Jesús, "Credit Supply and Monetary Policy: Identifying the Bank Balance- Sheet Channel with Loan Applications," American Economic Review, 2012, 102 (5), 2301-2326.

Jorda, O., M. Schularick, and A. Taylor, "When Credit Bites Back," Journal of Money, Credit and Banking, 2013, 45, 3-28. 
Kashyap, A and JC Stein, "The Impact of Monetary Policy on Bank Balance Sheets," Carnegie Rochester Conference Series on Public Policy, 1995, 42, 151-195.

_ and _, "What do a Million Observations on Banks Say about the Transmission of Monetary Policy," American Economic Review, 2000, 90 (3), 407-428.

Kashyap, Anil K, Jeremy C Stein, and David W Wilcox, "Monetary Policy and Credit Conditions: Evidence from the Composition of External Finance," American Economic Review, March 1993, 83 (1), 78-98.

Kishan, R. and T. Opiela, "Bank Size, Bank Capital, and the Bank Lending Channel," Journal of Money, Credit and Banking, 2000, 32, 121-141.

Kwan, S. and R. Eisenbeis, "An Analysis of Inefficiencies in Banking," Journal of Banking and Finance, 1995, 19, 733-734.

Lemke, Wolfgang and Andreea L. Vladu, "Below the zero lower bound: A shadow-rate term structure model for the euro area," Discussion Papers 32/2016, Deutsche Bundesbank, Research Centre 2016.

Marotta, Giuseppe, "Structural Breaks in the Lending Interest Rate Pass-Through and the Euro," Economic Modelling, 2009, 26 (1), 191-205.

Peek, J. and E. Rosengren, "Collateral Damage: Effects of the Japanese Bank Crisis on Real Activity in the United States," American Economic Review, 2000, 90, 30-45.

_ and _ , "Unnatural Selection: Perverse Incentives and the Misallocation of Credit in Japan," American Economic Review, 2005, 95, 1144-1166.

Peltzman, Sam, "Prices Rise Faster than They Fall," Journal of Political Economy, June 2000, 108 (3), 466-502.

Ritz, Robert and Ansgar Walther, "How do Banks Respond to Increased Funding Uncertainty," Journal of Finanical Intermediation, 2015, 24 (3).

Ruthenberg, David and Yoram Landskroner, "Loan pricing under Basel II in an imperfectly competitive banking market," Journal of Banking \& Finance, 2008, 32 (12), 2725-2733.

Sander, Harald and Stefanie Kleimeier, "Convergence in euro-zone retail banking? What interest rate pass-through tells us about monetary policy transmission, competition and integration," Journal of International Money and Finance, April 2004, 23 (3), 461-492.

Stineman, Russell W., "A consistently well-behaved method of interpolation," Creative Computing, 1980, $6(7), 54-57$.

Wu, Jing Cynthia and Fan Dora Xia, "Measuring the Macroeconomic Impact of Monetary Policy at the Zero Lower Bound," Journal of Money, Credit and Banking, 2016, 48 (2-3), 253-291. 